\title{
A Review of Hepatitis C in the General Population in Pakistan
}

\author{
Pakistan Toplumunda Hepatit C ile llgili Bir Gözden Geçirme
}

\author{
Sana RIAZ, Atia IOBAL \\ The Women University, Department of Microbiology and Molecular Genetics, Multan, Pakistan
}

\begin{abstract}
To perform a systematic review of the recent scientific literature on hepatitis C infection (2010-2016) for epidemiology, genotypes, co-infection, risk factors and management regime in Pakistan. Present integrated, analyzed updated data, a comprehensive effort to evaluate hepatitis $\mathrm{C}$ virus ( $\mathrm{HCV}$ ) disease burden in Pakistan, and to inform public health decision makers. Literature search was performed using PubMed, Google Scholar and Scopus from peerreviewed journals. Criteria for inclusion and exclusion of pooled data with reference to quality and relevance were set prior to metaanalysis. A total of 129 studies were finally included; more than one study on the same region or group of population was included for comparison and statistical authentication. Hepatitis $C$ is endemic in Pakistan with a $40 \%$ raise in the incidence of the disease conferring to resent reports. Data of the last five years from different districts of the country show an abrupt elevation in HCV seroprevalence. HCV genotype 3a remains to be the most prevalent in Pakistan (61.3\%). However, in recent years, genotype 1a has raised in the Baluchistan province. A significantly high prevalence in transfusion-transmitted diseases is observed. Management of known risk factor can be a significant parameter to control HCV infection. This review encourages further rigorous research efforts to analyze surveillance of HCV in ruler remote areas of Pakistan. Furthermore, facilitated access to clinical manifestations should be made to identify risk factors, reduce disease burden and to improve the quality of life of hepatitis $\mathrm{C}$ carriers.
\end{abstract}

Keywords: Hepatitis C, epidemiology, prevalence, genotype distribution, co-infection, transmission öz

Bu çalışmada Pakistan'da hepatit C enfeksiyonunun epidemiyolojisi, genotipleri, ko-enfeksiyonları, risk faktörleri ve yönetimi konusunda son dönem (2010-2016) bilimsel literatürlerin sistematik bir derlemesi yapılmıştır. Pakistan'daki hepatit $\mathrm{C}$ virüsü (HCV) hastalık yükünü değerlendirmek ve halk sağlığı uzmanlarını bilgilendirmek için, kapsamlı bir çalışmayla analiz edilen güncellenmiş veriler günümüze entegre edilmiştir. Literatür araştırmaları PubMed, Google Akademik ve Scopus kullanılarak hakemli dergilerden yapılmıştır. Kalite ve uygunluk için referansla toplanan verilerin dahil edilme ve edilmeme kriterleri meta-analiz için önceden belirlenmiştir. Karşılaştırma ve istatistiksel olarak doğrulama için, benzer bölge veya grup üzerinde birden fazla çalışma, sonuçta toplam 129 çalışma dahil edilmiştir. Güncel raporlara göre insidansta $\% 40$ artışla hepatit C Pakistan'da endemiktir. Ülkenin farklı kesimlerinden son 5 yıllık veriler, hepatit $\mathrm{C}$ seroprevalansında ani bir yükselişi göstermektedir. HCV 3a genotipi Pakistan'da en yaygın genotip olmaya devam etmektedir. Bununla birlikte son yıllarda genotip 1a Balunchistan eyaletinde artış göstermiştir. Transfüzyonla bulaşan hastalıklarda belirgin olarak yüksek bir prevalans gözlenmiştir. Bilinen risk faktörünün yönetimi HCV enfeksiyonunu kontrol etmek için önemli bir parametre olmalıdır. Bu çalışma Pakistan'ın kırsal bölgelerindeki HCV sürveyans analizi için gelecekte yapılacak araştırmaları teşvik edecektir. Ayrıca, risk faktörlerini belirlemek, hastalık yükünü azaltmak ve hepatit $\mathrm{C}$ taşıyıcılarının yaşam kalitesini artıımak için klinik bulguları kolaylaştırmak gerekir.

Anahtar Kelimeler: Hepatit C, epidemiyoloji, prevalans, genotip dağılımı, ko-enfeksiyon, bulaş

Riaz S, lqbal A. A Review of Hepatitis C in the General Population in Pakistan. Viral Hepat J. 2016;220:74-81.

\section{Introduction}

Hepatitis C virus (HCV) infection is the most distressing health dilemma worldwide. According to the recent reports of the World Health Organization (WHO), more than 185 million people of the world are infected with HCV (1). Hepatitis $\mathrm{C}$ is a predominant cause of chronic liver complications; one third of the infected patients are predicted to develop steatosis, hepatic cirrhosis or hepatocellular carcinoma (2). Despite of all therapeutic interventions, hepatitis $\mathrm{C}$ and its associated causes

Address for Correspondence: Sana Riaz MD, The Women University, Department of Microbiology and Molecular Genetics, Multan, Pakistan Phone: +03344031511 E-mail: sanariazk@gmail.com Received: 10.10.2016 Accepted: 02.12.2016

${ }^{\circ}$ Copyright 2016 by Viral Hepatitis Society / Viral Hepatitis Journal published by Galenos Yayınevi. 
are responsible for 350.000 deaths annually (3). Hepatitis $C$ is an asymptomatic infection and the patient remains unaware, but continuous fluctuation in liver enzymes may lead to hepatic injury (4). HCV is more prevalent in developing compared to that in developed countries due to lack of healthcare facilities, poor prognosis and high cost of the available treatments.

\section{Molecular Evolution of Hepatitis C Virus}

Choo et al. (4) in 1989, first identified HCV as an enveloped RNA virus. Previously, HCV was named as "non A, non B hepatitis" and was classified as a member of Flaviviridae family $(5,6)$ which also includes Dengue virus. However, the low sequence homology as compared to other flaviviruses eventually led to eastablishment of new hepacivirus family for HCV (7). There are some other hepatotrapic viruses identified as members of hepacivirus family which includes hepatitis A, B, D, E and G (Figure 1) (8).

Genetic sequence of HCV was first characterized in 1989 as highly variable genome with several genotypes which are about 9.6 $\mathrm{kb}$ in length (Figure 1) (9). These multiple genomes have high rate of mutation as alteration in sequence that is $1.44 \times 10-3$ nucleotide per site per annum. Similarly, an evolutionary rate of $7.4 \times 10-4$ nucleotide replacement per site per annum for E1 gene and 4.1×10-4 for the NS5B gene (10) has been identified. Due to this unusual mutational frequency of $\mathrm{HCV}$, development of an effective vaccine is a challenge for scientists and researchers all over the world. How and when HCV was transmitted to human population from Ape species is still a mystery. Moreover, both host and viral factors associated with molecular and cellular mechanism of HCV are not entirely explored. Molecular cloning technique is used for identification and characterization of HCV using blood serum of the infected individual (11). For the confirmation of viremia, initial serological screening is followed by quantitative HCV RNAbased polymerase chain reaction analysis (6). The prime objective of present review was to analyze current epidemiology of $\mathrm{HCV}$ infecton in Pakistan through comprehensive literature evaluation of the last decade.

\section{Epidemiology}

The WHO estimates that more than $3 \%$ of the world population (WHO 2014) is living with hepatitis C. Globally, hepatitis C disease burden has a variable geographical distribution whereas, high prevalence is observed in East and Central Asia followed by North Africa and Middle Eastern counties. As larger population resides in the Asian and African regions, the highest prevalence is observed there as compare to rest of the world (11). Almost 3.7\% of Eastern Asia, 3.6\% of Middle East and 3.4\% of South Asia populations are struggling with hepatitis $C(10)$. The prevalence of $\mathrm{HCV}$ infection is estimated at $6 \%$ in Pakistan (12), $1.5 \%$ in India (13), and 2.2\% China (14). However, in underdeveloped countries of Asia, there is lack of authentic data about the disease burden. On the contrary, the developed nations of North America, Western Europe and Australia have low HCV seroprevalence rate i.e. 0.63\% in Germany (15), $1 \%$ in Canada and $1.1 \%$ in Australia (12). Slightly higher seroprevalence has been reported in some other developed countries like USA (1.7\%) (16).

Identification of HCV genotype is critically important for the duration of treatment (17). HCV genotyping is utilized for the production of genotype-specific HCV antibodies. Geographical distribution of genotypes has variable frequency. In West African countries, genetically most diverse genotypes 1 and 2 are more frequent (18). In China and Japan, most HCV infections are due to genotype $1 b$, whereas genotype 4 is frequently found in Middle East (18) and genotype $5 a$ in South Africa (19). On the other hand, genotype $3 \mathrm{a}$ and $1 \mathrm{~b}$ are more prevalent in Iran, Pakistan and India (20). Patients with HCV genotype $3 a$ are found to be at an accelerated risk of steatosis and hepatic fibrosis whereas, severe liver disease has been reported in patients with chronic HCV genotype $1 \mathrm{~b}(21)$.

\section{Hepatitis C Prevalence in Pakistan}

HCV infection is endemic in Pakistan (22,23,24,25); according to a recent report, the incidence of the disease has increased from $4.7 \%(41)$ to $6.8 \%$ within a couple of years (28). Unfortunately, low literacy level, inadequate public health facilities and lack of awareness are main reasons behind insufficiency of significant data about the high incidence of the disease in Pakistan. Several studies have reported various HCV infection rates in different geographical areas and ethnic groups in Pakistan $(25,26,36,64)$. In this review, we investigated more than twenty articles on the prevalence of $\mathrm{HCV}$ in the country published recently in national and international journals (Table 1).

Majority of the population has never been screened for hepatitis and many individuals have been diagnosed but remained untreated throughout their life. There is no mechanism for the screening of $\mathrm{HCV}$ in remote areas and villages of the country where more than $60 \%$ of the population is living (68) and ten million people $(28,29,30)$ are reported to have HCV infection. An increase in disease burden is observed in the provinces of Pakistan (31). Data from selected districts of the most populous province Punjab

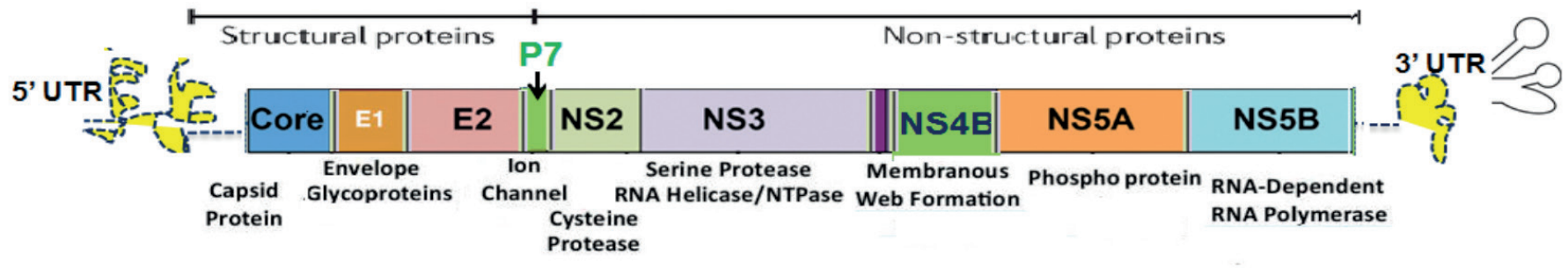

Hepatitis C virus

Figure 1. Hepatitis $C$ virus genome 
discloses heterogenous results of HCV seroprevalence in recent years. The districts of Punjab include Lahore, Multan, Faisalabad, Gujranwala and Rahimyar Khan (Table 1).

In federal capital Islamabad, the prevalence reported in recent years is 33\% in selected group of population. Whereas, studies conducted in different districts of the Khyber Pakhtun Khwa (KPK) province revealed anti-HCV seroprevalence in district Mardan and Mansehra, from Azad Kashmir districts Kotli and Mirpur. Studies of HCV prevalence over the last five years in Sindh Province included the districts of Karachi and Hyderabad. A resent research conducted on HCV frequency in the district of Baluchistan included the provinces of Quetta and Sibi. This review reveals that there are only limited number of studies available in some high prevalence districts, such as Sibi, Mirpur and Kotli. Unfortunately, lack of reports from tribal areas, Gilgit Baltistan, indicates the need for comprehensive studies in these areas (69).

\begin{tabular}{|c|c|c|}
\hline Districts & Anti-HCV seroprevalence & Reference \\
\hline Islamabad & $33 \%$ & (32) \\
\hline Faisalabad & $22.68 \%$ & (33) \\
\hline Karachi & $6.8 \%$ & (34) \\
\hline Karachi & $7.6 \%$ & $(50)$ \\
\hline Multan & $3.44 \%$ & (35) \\
\hline Multan & $6.68 \%$ & $(45)$ \\
\hline Mardan & $64.2 \%$ & (37) \\
\hline Gujranwala & $5.16 \%$ & $(30)$ \\
\hline Gujranwala & $3 \%$ & (35) \\
\hline Lahore & $7.3 \%$ & (38) \\
\hline Faisalabad & $21.9 \%$ & (29) \\
\hline Islamabad & $23.5 \%$ & $(40)$ \\
\hline Karachi & $2.61 \%$ & $(42)$ \\
\hline Lahore & $4.9 \%$ & $(41)$ \\
\hline Lahore & $15.1 \%$ & (73) \\
\hline Mardan & $6.46 \%$ & $(22)$ \\
\hline Quetta & $20.8 \%$ & (43) \\
\hline Quetta & $8.9 \%$ & $(45)$ \\
\hline Sibi & $9.3 \%$ & (74) \\
\hline Mirpur & $2.5 \%$ & $(47)$ \\
\hline Kotli & $6.38 \%$ & $(70)$ \\
\hline Hyderabad & $8 \%$ & (33) \\
\hline Mansehra & $7 \%$ & $(50)$ \\
\hline Karachi & $25.1 \%$ & $(51)$ \\
\hline
\end{tabular}

\section{Hepatitis C Virus Genotype Distribution Pattern in Pakistan}

A comprehensive knowledge of HCV genotypes with reference to the geographical location is often significant for determination of severity and treatment regimen. There are various studies that have established a relationship between genotype and their distribution pattern for better understanding of epidemiological complications $(40,41,42,43,44,45)$. However, genotype determination is an expensive procedure which is carried out by sequencing HCV genome at 5'untranslated region or NS5b region (49). Several research groups have shown that $\mathrm{HCV}$ infection genotype 3 a is most prevalent in Pakistan, followed by untypeable and 1a genotypes $(35,50,52)$. Whereas untypeable infection remains the second most frequent genotype in population studied (46). Similarly, in this review, all reports have stated the same prevalence order of $\mathrm{HCV}$ genotypes in Pakistan (Figure 2). Punjab, the largest province of the country, has been reported to have the highest prevalence of $\mathrm{HCV}$ infection $(55,56)$. Similarly, different reports based on data from Sindh and KPK province revealed that genotype $3 a$ and $1 a$ were the most prevalent genotypes, respectively. Pakistan shares its long eastern boarders with India where 3a genotype is the most frequent.

However, the data from Baluchistan, geographically the largest province in Pakistan, has shown some variation. According to some studies, genotype 1a, followed by $3 a$, is predominant in Baluchistan. It is considered that this variation is due to the fact that Iran lies at the western borders of the country. In Iran, 1a is the most frequent genotype (57). Possible shift observed in genotype pattern in KPK is may be due to high mutation or recombination rate in HCV sequence, lack of sensitivity of the present genotyping methods and the migrants from Afghanistan border to tribal regions, and internally displaced people due to war on terror (58). The geographical distribution pattern of HCV genotype is diverse from the rest of the world on the basis of clinical diagnostic methods (59). As untypable, unknown genotypes remain to be second predominant genotype existing in the country. This fact is supported by various studies conducted in Pakistan in the recent years $(60,61,62)$. Therefore, it is a significant challenge for researchers to optimize protocols to sequence the genome of the untypeable genotypes.

\section{Hepatitis C Virus Co-Infections}

According to the $\mathrm{WHO}$ recommendations, every blood donor should be screened out for at least five transfusion-transmitted

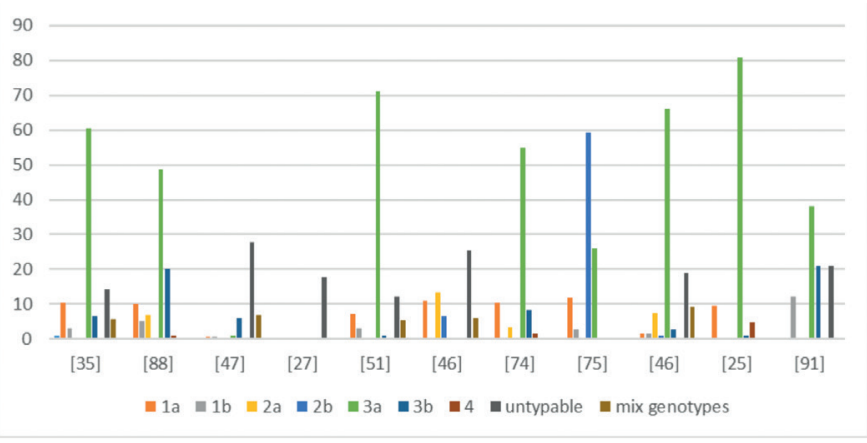

Figure 2. Distribution of hepatitis $C$ virus genotype pattern 
infections, such as hepatitis C, hepatitis B, HIV malarial parasite, and syphilis (10). Among donor population, these infectious diseases are the major health concern in developing countries including Pakistan. In case of co-management sound clinical consideration is required to avoid the risks. Limited studies have been conducted in Pakistan which demonstrated an increased rate of co-infection with hepatitis C and hepatitis B virus (HBV), thalassemia and tuberculosis. HBV and HCV co-infection mostly occur in HBV endemic areas, thus, dual infection in Pakistan has been studied by different research groups $(64,86,93)$. Injection drug users (IDU's) have highest rate of HCV and HBV co-infection (69). According to reports from different parts of the country, the prevalence of this co-infection is alarming [0.7\% (65) and 3.9\% (66)].

Almost $10 \%$ of the population of Pakistan is suffering from diabetes mellitus (10). Coexistence of diabetes and HCV infection caused by blood transfusion, surgery, and unsafe insulin syringes is a major health issue. Two studies including data of registered diabetic patients for the screening anti-HCV antibodies has shown the prevalence of 9.3\% (68) and 33\% (77). Thalassemia is an inherited haemoglobinopathy and the recommended treatment is blood transfusion (70). These transfusions increase the risk of hepatitis $C$ and other transfusion-transmitted diseases if transfusion is made from unscreened donors. According to a study (71), 68.2\% of thalassemia patients were screened out for hepatitis $\mathrm{C}$ co-infection. During blood transfusion, each time a new, separate syringe can prevent the transmission of HCV in thalassemia patients (72). The frequency of HCV co-infection is illustrated in Figure 3.

Tuberculosis is endemic in regions where blood products are not screened before practice (40). The prevalence of HCV among tuberculosis patients has not been extensively studied in Pakistan (23). HCV and tuberculosis co-infection which increase the risk of liver failure, is $17.02 \%$ (67). HIV infection is a serious

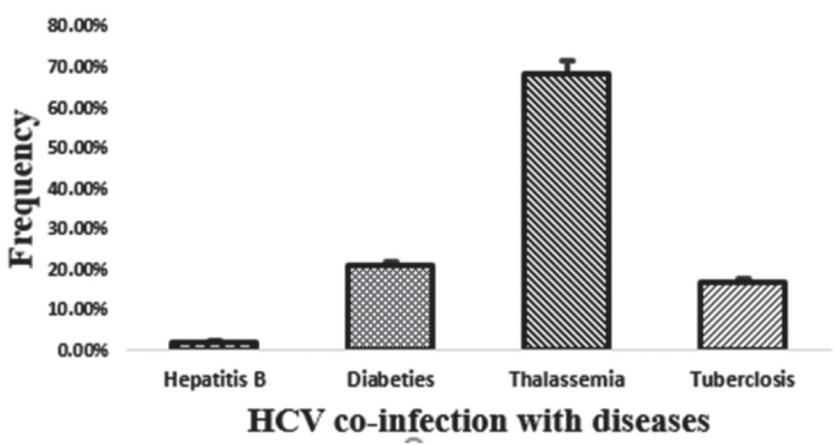

Figure 3. Frequency of hepatitic C infection with hepatitis B, diabeties, thalassemia and tuberclosis HCV: Hepatitis $C$ virus

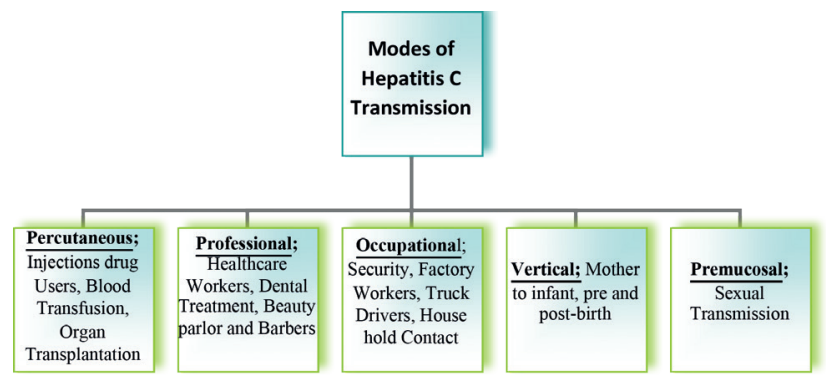

Figure 4. Modes of hepatitis $C$ transmission life-threatening opportunistic condition. Various reports showed that the incidence of the disease in Pakistan varied between $0.1 \%$ (53) and $0.017 \%$ (75). Whereas, no subjects were found with HCV and HIV co-infection in other studies (93). The frequency of $\mathrm{HCV}$ infection in post-surgery patients in Pakistan is alarming (33). Therefore, pre- and post-surgery serological screening should be performed. Furthermore, the major cause of HCV infection and its co-infections in Pakistan are unsafe blood transfusions (40). In 2003, a comprehensive national blood screening policy was lauched (81) as per recommended protocol of WHO. However, in underdeveloped and remote areas of the country, blood screening policy still needs to be implemented for controlling the frequency of transfusion-transmitted diseases.

\section{Modes of Hepatitis C Virus Transmission}

$\mathrm{HCV}$ infection is intensely associated with imbalance healthcare facilities in different regions of Pakistan. Major causes of transmission are given in Figure 4. There are 12 billion injections administered throughout the world per annum (80), with more than $45 \%$ considered unsafe are practiced in African and Asian countries $(81,82)$. Whereas, Pakistan has the highest frequency of therapeutic intramuscular injections per person annually (83). An elevation in HCV infection rates is observed due to IDU's sharing syringes. Drug equipment and unscreened or inadequately screened blood transfusions $(85,86)$. Nevertheless, hepatitis $C$ is proficiently transmitted through transplantation of infected organs and hemodialysis units (87). Various reports on blood donors have shown reduction in hepatitis $\mathrm{C}$ frequency through blood transfusions with different prevalence rates such as, 8.34\% (20) $7.1 \%$ (89) $20.8 \%$ (90), which was $68.2 \%$ in another study (Figure 4) (71).

A recent research in Pakistan demonstrated that second major risk factor responsible for blood-borne transmission of hepatitis $\mathrm{C}$ was occupation. There have been studies showing the prevalence of $\mathrm{HCV}$ infection to be varying between $4.13 \%$ and $10 \%$ among the healthcare workers (90), 38\% (91) and $28.10 \%$ (92) among barbers, while dental procedures were found to account for 24.54\% (94) and $14.2 \%$ (99) (Figure 5). In Pakistan, tattooing is least affecting risk factor on contrary to that in the rest of the world. Some of the hepatitis $\mathrm{C}$ infection studies conducted on the prevalence among people belonging to different professions showed 3.13\% among Punjab Rangers (94), 14.7\% in truck

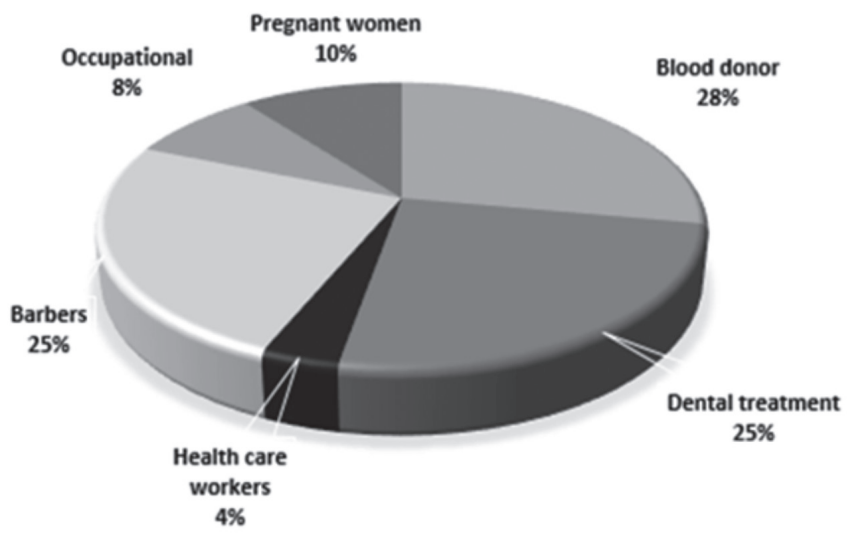

Figure 5. Major risk factors of hepatitis in Pakistan 
drivers (95) and $11.38 \%$ among factory workers (30). However, it was observed that $36.2 \%$ of persons with $\mathrm{HCV}$ antibodies were sharing tooth brush, razors, nail cutters and house hold personal belongings (97). Vertical transmission of hepatitis $C$ refers to viral transmission from the mother to the infant. Recently, in a couple of studies, the prevalence of HCV among pregnant women was found to be between $13.3 \%$ (98) and $3.45 \%$ (99). Viral RNA has been identified in breast milk and colostrum; breast feeding is not a significant risk for mother to infant transmission unless the nipples are intact (100). Even though, HCV RNA has been identified in semen, vaginal fluid, and cervical smears yet, sexual transmission is infrequent (101).

$\mathrm{HCV}$ is more frequent among men who have sex with men, heterosexual partners and sex workers (102). Other factors associated with high hepatitis $C$ prevalence comprises of illiteracy, untrained health professionals, and compromised economic background Ford et al. (102). Hence, various awareness programs, basic education and healthcare facilities for all can reduce the prevalence of hepatitis C (104).

\section{Disease Management}

With the advances in therapeutic interventions, hepatitis $\mathrm{C}$ is curable now and a recovered individual cannot transmit the infection. Previously, the only available therapy was interferon for 6 to 24 weeks (3 million international units) or the same intravenous dose of interferon for 4 to 7 weeks (105). Since 2001, pegylated interferon a with ribavirin has shown favorable results against genotype 2 and 3 (106). Nevertheless, this combination therapy has limited efficacy as well as some adverse effects and low response rate against genotype 1 (107). Currently, for disease management, four new drugs including the protease inhibitors boceprevir, simeprevir, telaprevir are being licensed for HCV genotype 1. A new polymerase inhibitor, sofosbuvir, effective against HCV genotypes 2 and 3 (10), is available on reduced price in Pakistan. These drugs have reduced the risk of hepatocellular carcinoma $(107,108)$. However, telaprevir has been shown to be associated with side effects, such as anemia, rash and pruritus $(103,110)$. This fact emphasizes the inevitability of cost effective, efficient and least toxic hepatitis C therapeutic drugs. Recently, few more HCV inhibitors are at different stages of clinical trials (111).

\section{Conclusion}

This systematic review is a pooled analysis to estimate the disease burden attributable to HCV infection. More than 10 million people in Pakistan are suffering from HCV infection, the facts are even worse because there is no data available from remote areas of the country. HCV genotype $3 a$ is the most prevalent genotype in Pakistan. Prediction of genotype assists in selection and time duration of antiviral therapy. Limited studies conducted on HCV co-infections in Pakistan yet their facts and figures are distressing. Moreover, inadequate healthcare services, illiteracy, high cost prognosis and treatment options are barriers in the way to overcome the high prevalence of HCV infection in Pakistan. Furthermore, comprehensive educational awareness seminars concerning preventive measures and risk factors must be arranged on regular basis for the general population. There is an intense need for the establishment of hepatitis clinical research network and administration of database for HCV screening nationwide.

\section{Ethics}

Peer-review: Externally and Internally peer-reviewed.

\section{Authorship Contributions}

Concept: Sana Riaz, Atia lqbal, Design: Sana Riaz, Atia lqbal, Data Collection or Processing: Sana Riaz, Atia lqbal, Analysis or Interpretation: Sana Riaz, Atia lqbal, Literature Search: Sana Riaz, Atia lqbal, Writing: Sana Riaz, Atia lqbal.

Conflict of Interest: No conflict of interest was declared by the authors.

Financial Disclosure: The authors declared that this study received no financial support.

\section{References}

1. Mohd Hanafiah K, Groeger J, Flaxman AD, Wiersma ST. Global epidemiology of hepatitis $C$ virus infection: New estimates of age-specific antibody to HCV seroprevalence. Hepatology. 2013;57:1333-1342

2. He S, Lin B, Chu V, Hu Z, Hu X, Xiao J, Wang AQ, Schweitzer CJ, Li Q, Imamura M, Hiraga N, Southall N, Ferrer M, Zheng W, Chayama $\mathrm{K}$, Marugan JJ, Liang TJ. Repurposing of the antihistamine chlorcyclizine and related compounds for treatment of hepatitis C virus infection. Sci Transl Med. 2015;7:282-249.

3. Ekstedt M, Franzen LE, Mathiesen UL, Thorelius L, Holmqvist M, Bodemar G, Kechagias S. Long-term follow-up of patients with NAFLD and elevated liver enzymes. Hepatology. 2006;44:865873.

4. Choo QL, Kuo G, Weiner AJ, Overby LR, Bradley DW, Houghton $\mathrm{M}$. Isolation of a cDNA clone derived from a blood-borne non-A, non-B viral hepatitis genome. Science. 1989;244:359-362.

5. Zaman AA, Karim R, Khan ST, Khan SA. Frequecny of hbsag and anti-hcv in asymptomatic healthy blood donors at hmc, Peshawar. KJMS. 2014;1:155-158.

6. Hill AM, Roberts T, Amorosa V, Pourmand K, Matthews G, Cooke G, Khan H, Main J, Brown A, Peter JA, Nelson DR. Can HCV Antigen Testing Replace HCV RNA PCR Analysis, for Diagnosis and Monitoring of Treatment for Hepatitis C?. In Hepatology 2015;07030-5774

7. Zidan A, Scheuerlein H, Schüle S, Settmacher U, Rauchfuss F Epidemiological pattern of hepatitis $B$ and hepatitis $C$ as etiological agents for hepatocellular carcinoma in iran and worldwide. Hepat Mon. 2012;12:e6894.

8. Debing $Y$, Jochmans $D$, Neyts J. Intervention strategies for emerging viruses: use of antivirals. Curr Opin Virol. 2013;3:217224

9. Giang E, Dorner M, Prentoe JC, Dreux M, Evans MJ, Bukh J, Rice CM, Ploss A, Burton DR, Law M. Human broadly neutralizing antibodies to the envelope glycoprotein complex of hepatitis $C$ virus. Proc Natl Acad Sci U S A. 2012;109:6205-6210.

10. WHO Guidelines Approved by the Guidelines Review Committee. Guidelines for the screening, care and treatment of persons with hepatitis C infection. Geneva: World Health Organization; 2014. 
11. Bruggmann $\mathrm{P}$, Berg $\mathrm{T}$, Ovrehus $\mathrm{AL}$, Moreno $\mathrm{C}$, Brandao Mello $\mathrm{CE}$, Roudot-Thoraval F, Marinho RT, Sherman M, Ryder SD, Sperl J, Akarca U, Balık I, Bihl F, Bilodeau M, Blasco AJ, Buti M, Calinas F, Calleja $\mathrm{JL}$, Cheinquer H, Christensen PB, Clausen M, Coelho HS, Cornberg M, Cramp ME, Dore GJ, Doss W, Duberg AS, El-Sayed MH, Ergör G, Esmat G, Estes C, Falconer K, Felix J, Ferraz ML, Ferreira PR, Frankova S, Garcia-Samaniego J, Gerstoft J, Giria JA, Gonçales FL Jr, Gower E, Gschwantler M, Guimaraes Pessoa M, Hezode C, Hofer $H$, Husa P, Idilman R, Kaberg M, Kaita KD, Kautz A, Kaymakoglu S, Krajden M, Krarup H, Laleman W, Lavanchy D, Lazaro P, Marotta P, Mauss S, Mendes Correa MC, Müllhaupt B, Myers RP, Negro F, Nemecek V, Örmeci N, Parkes J, Peltekian KM, Ramji A, Razavi H, Reis N, Roberts SK, Rosenberg WM, Sarmento-Castro R, Sarrazin C, Semela D, Shiha GE, Sievert W, Starkel P, Stauber RE, Thompson AJ, Urbanek P, van Thiel I, Van Vlierberghe H, Vandijck D, Vogel W, Waked I, Wedemeyer H, Weis N, Wiegand J, Yosry A, Zekry A, Van Damme P, Aleman S, Hindman SJ. Historical epidemiology of hepatitis C virus (HCV) in selected countries. J Viral Hepat. 2014;21 Suppl 1:5-33.

12. Lavanchy D. Evolving epidemiology of hepatitis C virus. Clin Microbiol Infect. 2011;17:107-115.

13. Dhiman RK. Future of therapy for Hepatitis $C$ in India: A Matter of Accessibility and Affordability?. J Clin Exp Hepatol. 2014;4:85-86.

14. Lavanchy D. The global burden of hepatitis C. Liver Int. 2009;29 Suppl 1:74-81.

15. Vermehren J, Sarrazin C. The role of resistance in HCV treatment. Best Pract Res Clin Gastroenterol. 2012;26:487-503.

16. Sy T, Jamal MM. Epidemiology of hepatitis $\mathrm{C}$ virus (HCV) infection. Int J Med Sci. 2006;3:41-46.

17. Chinchai $T$, Labout J, Noppornpanth $S$, Theamboonlers $A$, Haagmans BL, Osterhaus AD, Poovorawan Y. Comparative study of different methods to genotype hepatitis $C$ virus type 6 variants. J Virol Methods. 2003;109:195-201.

18. Abdelwahab SF, Hashem M, Galal I, Sobhy M, Abdel-Ghaffar TS, Galal G, Mikhail N, El-Kamary SS, Waked I, Strickland GT. Incidence of hepatitis $\mathrm{C}$ virus infection among Egyptian healthcare workers at high risk of infection. J Clin Virol. 2013;57:24-28.

19. Al Naamani K, Al Sinani S, Deschenes M. Epidemiology and treatment of hepatitis $\mathrm{C}$ genotypes 5 and 6. Can J Gastroenterol. 2013;27:e8-12.

20. Trinks J, Gadano A, Argibay P. Evolving trends in the hepatitis C virus molecular epidemiology studies: from the viral sequences to the human genome. Epidemiology Research International. 2012.

21. Afridi SQ, Zahid MN, Shabbir MZ, Hussain Z, Mukhtar N, Tipu MY, Akhtar F, Yaqub T. Prevalence of HCV genotypes in district Mardan. Virol J. 2013;10:90.

22. Umar S, Waheed Y, Ashraf M. Hepatitis B and hepatitis C viruses: a review of viral genomes, viral induced host immune responses, genotypic distributions and worldwide epidemiology. Asian Pac J Trop Biomed. 2014;4:88-96.

23. Zein NN, Abdulkarim AS, Wiesner RH, Egan KS, Persing $\mathrm{DH}$. Prevalence of diabetes mellitus in patients with end-stage liver cirrhosis due to hepatitis $\mathrm{C}$, alcohol, or cholestatic disease. J Hepatol. 2000;32:209-217.

24. Rasheed A, Ullah S, Naeem S, Zubair M, Ahmad W, Hussains Z. Occurrence of HCV genotypes in different age groups of patients from Lahore, Pakistan. ALS. 2014;2:89-95.

25. Afridi SQ, Ali MM, Awan F, Zahid MN, Afridi IQ, Afridi SQ, Yaqub T. Molecular epidemiology and viral load of HCV in different regions of Punjab, Pakistan. Virol J. 2014;11:24

26. Butt $\mathrm{S}$, Idrees M, Akbar H, ur Rehman I, Awan Z, Afzal S, Hussain A, Shahid M, Manzoor S, Rafique S. The changing epidemiology pattern and frequency distribution of hepatitis $\mathrm{C}$ virus in Pakistan. Infect Genet Evol. 2010;10:595-600.

27. Muhammad U, Bilal M. Hepatitis $\mathrm{C}$, a mega menace: a Pakistan Perspective. Journal of Pioneering Medical Sciences. 2012;2:68.
28. Furuta A, Salam KA, Akimitsu N, Tanaka J, Tani H, Yamashita A, Moriishi K, Nakakoshi M, Tsubuki M, Sekiguchi Y, Tsuneda S, Noda N. Cholesterol sulfate as a potential inhibitor of hepatitis C virus NS3 helicase. J Enzyme Inhib Med Chem. 2014;29:223-229.

29. Akhtar J, Qamar MU, Hakeem A, Waheed A, Sarwar F, Anwar J. Seroprevalence of HBV and HCV in Tuberculous Patients at Sheikh Zayed Hospital Rahim Yar Khan, Pakistan. Biomedica. 2013;29:69-72.

30. Ilyas JA, Vierling JM. An overview of emerging therapies for the treatment of chronic hepatitis C. Clin Liver Dis. 2011;15:515-536.

31. Asad M, Ahmed F, Zafar H, Farman S. Frequency and determinants of Hepatitis $B$ and $C$ virus in general population of Farash Town, Islamabad. Pak J Med Sci. 2015;31:1394-1398.

32. Khalid A, Zahid M, Aslam Z, Bilal M, Haider A. Sero-Epidemiology of Hepatitis B and C Virus in Rural Population of Tehsil Samundri, District Faisalabad, Pakistan. International Journal of Virology and Molecular Biology. 2015;4:19-22.

33. Rafaqat B, Ahmed M, Aziz A, Sultan N. Hepatitis B and C Virus Infection in Surgical Practice. Journal of Surgery Pakistan. 2015;20:64-67.

34. Hussain A, Mumtaz HM, Aslam MS, Abbas Z. Seroprevalence of transfusion based transmissible infections among clinically healthy donors in the community of Multan Pakistan. J Inf Mo Bio. 2015;3:47-51.

35. Grebely J, Page K, Sacks-Davis R, van der Loeff MS, Rice TM, Bruneau J, Morris MD, Hajarizadeh B, Amin J, Cox AL, Kim AY, McGovern BH, Schinkel J, George J, Shoukry NH, Lauer GM, Maher L, Lloyd AR, Hellard M, Dore GJ, Prins M; InC3 Study Group. The effects of female sex, viral genotype, and IL28B genotype on spontaneous clearance of acute hepatitis $\mathrm{C}$ virus infection. Hepatology. 2014;59:109-120.

36. Zubair AK, Shafiq M, Shahab F. Frequency and risk factors of hepatitis b\&c in afghan patients presenting to tertiary care hospital in peshawar. Pakistan Armed Forces Medical Journal. 2015;65:686-689

37. Ahmad T, Yin P, Saffitz J, Pockros PJ, Lalezari J, Shiffman M, Freilich B, Zamparo J, Brown K, Dimitrova D, Kumar M, Manion D, HeathChiozzi M, Wolf R, Hughes E, Muir AJ, Hernandez AFCardiac dysfunction associated with a nucleotide polymerase inhibitor for treatment of hepatitis C. Hepatology. 2015;62:409-416.

38. Rasheed A, Ullah S, Naeem S, Zubair M, Ahmad W, Hussain $Z$. Occurrence of HCV genotypes in different age groups of patients from Lahore, Pakistan. Advancements in Life Sciences. 2014;1:89-95

39. Khan J, Shafiq M, Mushtaq S, Ayaz S, Ullah R, Naser M, AbdEISalam A, Fouad H, Wasim MA. Seropositivity and coinfection of hepatitis $\mathrm{B}$ and $\mathrm{C}$ among patients seeking hospital care in Islamabad, Pakistan. BioMed. 2014.

40. Abdul Majeed A, Majeed S, Majeed S, Javed H. Hepatitis C Virus Infection in Pregnant Women in Lahore, Pakistan: An Analytical Cross Sectional Study. International Journal of Agriculture Biology 2014;16:160-164.

41. Irfan SM, Uddin J, Zaheer HA, Sultan S, Baig A. Trends in transfusion transmitted infections among replacement blood donors in karachi, Pakistan. Turk J Haematol. 2013;30:163-167.

42. Khan A, Tareen AM, Ikram A, Rahman H, Wadood A, Qasim M, Khan K. Prevalence of HCV among the young male blood donors of Quetta region of Balochistan, Pakistan. Virol J. 2013;10:83.

43. Munir M, Shams S, Lodhi MA, Parveen Z, Ullah N. Prevalence of Hepatitis B in the Students, and Employees of Abdul Wali Khan University Mardan Shankar Campus. Pakhtunkhwa J Life Sci. 2013;3:120-129

44. Mengal MA, Abbas F, Mengal MA, Shafee M, Babar S, Mengal MA, Atique MS. Passive surveillance of anti-hepatitis $C$ virus antibodies in human subjects of four medical units of Balochistan, Pakistan. International Journal of Agriculture and Biology. 2012;14:585-589. 
45. Ali S, Ahmad A, Khan RS, Khan S, Hamayun M, Khan SA, labal A, Khan AA, Wadood A, Ur Rahman T, Baig AH. Genotyping of HCV RNA reveals that $3 a$ is the most prevalent genotype in mardan, pakistan. Adv Virol. 2014;2014:606201.

46. Sohail U, Satapathy SK. Diagnosis and management of alcoholic hepatitis. Clin Liver Dis. 2012;16:717-736.

47. Akbar $\mathrm{H}$, Idrees M, Butt S, Awan Z, Sabar MF, Rehaman Iu, Hussain A, Saleem S. High baseline interleukine-8 level is an independent risk factor for the achievement of sustained virological response in chronic HCV patients. Infect Genet Evol. 2011;11:1301-5130

48. Bacon $B R$, Khalid O. New therapies for hepatitis $\mathrm{C}$ virus infection. Mo Med. 2011;108:255-259

49. Ali A, Ahmed H, Idrees M. Molecular epidemiology of Hepatitis C virus genotypes in Khyber Pakhtoonkhaw of Pakistan. Virol J. 2010;7:203.

50. Aziz S, Khanani R, Noorulain W, Rajper J. Frequency of hepatitis $B$ and $C$ in rural and periurban Sindh. J Pak Med Assoc. 2010;60:853-857

51. Idrees M, Riazuddin S. A study of best positive predictors for sustained virologic response to interferon alpha plus ribavirin therapy in naive chronic hepatitis C patients. BMC Gastroenterol. 2009;9:5

52. Afzal MS, Anjum S, Zaidi NU. Effect of Functional Interleukin-10 Polymorphism on Pegylated Interferon- Plus Ribavirin Therapy Response in Chronic Hepatitis C Virus Patients Infected With 3a Genotype in Pakistani Population. Hepat Mon. 2013;13:e10274.

53. Wagar $M$, Khan $A U$, Rehman HU, Idrees $M$, Wasim M, Ali A, Niaz Z, Ismail Z, Rehman MU, Tariq M, Shah M, Murtaza BN. Determination of hepatitis $C$ virus genotypes circulating in different districts of Punjab (Pakistan). Eur $\mathrm{J}$ Gastroenterol Hepatol. 2014;26:59-64.

54. Ali MK, Light JA, Barhyte DY, Sasaki TM, Currier CB Jr, Grandas O, Fowlkes D. Donor hepatitis $C$ virus status does not adversely affect short-term outcomes in $\mathrm{HCV}+$ recipients in renal transplantation. Transplantation. 1998;66:1694-1697.

55. Butt AA, Khan UA, Shaikh OS, McMahon D, Dorey-Stein Z, Tsevat J, Lo Re V. Rates of HCV treatment eligibility among HCVmonoinfected and HCV/HIV-coinfected patients in tertiary care referral centers. HIV Clin Trials. 2009;10:25-32.

56. Ramezani A, Amirmoezi R, Volk JE, Aghakhani A, Zarinfar N, McFarland W, Banifazl M, Mostafavi E, Eslamifar A, Sofian M. $\mathrm{HCV}, \mathrm{HBV}$, and HIV seroprevalence, coinfections, and related behaviors among male injection drug users in Arak, Iran. AIDS Care. 2014;26:1122-1126.

57. Khubaib B, Saleem S, Idrees M, Afzal S, Wasim M. The genotype CC of IL 28B SNP rs12979860 is significantly associated with a sustained virological response in chronic HCV infected Pakistani patients. J Dig Dis. 2015;16:293-298.

58. Athar MA, Xu Y, Xie X, Xu Z, Ahmad V, Hayder Z, Hussain SS, Liao Y, Li Q. Rapid detection of HCV genotyping $1 \mathrm{a}, 1 \mathrm{~b}, 2 \mathrm{a}, 3 \mathrm{a}, 3 \mathrm{~b}$ and $6 a$ in a single reaction using two-melting temperature codes by a real-time PCR-based assay. J Virol Methods. 2015;222:85-90.

59. Bakhshipour A, Sargolzaie N, Kiani M, Barazesh F. Hepatitis C Virus Genotypes in Patients Referred to Educational Hospitals in Zahedan (2009-2013). Int J Infect. 2016;3:e34666.

60. Mustafa GM, Larry D, Petersen JR, Elferink CJ. Targeted proteomics for biomarker discovery and validation of hepatocellular carcinoma in hepatitis C infected patients. World J Hepatol. 2015;7:13122134.

61. Ohno O, Mizokami M, Wu RR, Saleh MG, Ohba K, Orito E, Mukaide M, Williams R, Lau JY. New hepatitis C virus ( $\mathrm{HCV}$ ) genotyping system that allows for identification of $\mathrm{HCV}$ genotypes 1a, 1b, 2a, 2b, 3a, 3b, 4, 5a, and 6a. J Clin Microbiol. 1997:35:201-207.
62. Idrees $\mathrm{M}$, Riazuddin S. Frequency distribution of hepatitis $\mathrm{C}$ virus genotypes in different geographical regions of Pakistan and their possible routes of transmission. BMC Infect Dis. 2008;8:69.

63. Ahmad W, ljaz B, Javed FT, Jahan S, Shahid I, Khan FM, Hassan S. HCV genotype distribution and possible transmission risks in Lahore, Pakistan. World J Gastroenterol. 2010;16:4321-4328.

64. Khan S, Attaullah S, Ayaz S, Niaz Khan S, Shams S, Ali I, Bilal M, Siraj S. Molecular epidemiology of hcv among health care workers of khyber pakhtunkhwa. Virol J. 2011;8:105.

65. Monto A, Dove LM, Bostrom A, Kakar S, Tien PC, Wright TL. Hepatic steatosis in HIV/hepatitis C coinfection: prevalence and significance compared with hepatitis C monoinfection. Hepatology. 2005;42:310-316.

66. Jayasekera CR, Barry M, Roberts LR, Nguyen MH. Treating hepatitis C in lower-income countries. N Engl J Med. 2014;370:1869-1871.

67. Basit A, Rahim K, Ahmad I, Shafiq M, Mushtaq S, Shaheen H, Khan I. Prevalence of Hepatitis B and C Infection in Pakistan. J Inf Mol Biol. 2014;2:35-38.

68. Junejo SA, Khan NA, Lodhi AA. Prevalence of hepatitis $B$ and $C$ infection in patients admitted at tertiary eye care centre: A hospital based study. Pak J Med Sci. 2009;25:597-600.

69. Hashmi A, Saleem K, Soomro JA. Prevalence and factors associated with hepatitis $\mathrm{C}$ virus seropositivity in female individuals in islamabad, pakistan. Int J Prev Med. 2010;1:252-256.

70. Janjua NZ, Hamza HB, Islam M, Tirmizi SF, Siddiqui A, Jafri W, Hamid S. Health care risk factors among women and personal behaviours among men explain the high prevalence of hepatitis $\mathrm{C}$ virus infection in Karachi, Pakistan. J Viral Hepat. 2010;17:317-326.

71. el-Danasoury AS, Eissa DG, Abdo RM, Elalfy MS. Red blood cell alloimmunization in transfusion-dependent Egyptian patients with thalassemia in a limited donor exposure program. Transfusion. 2012;52:43-47.

72. Aslam M, Aslam J. Seroprevalence of the antibody to hepatitis $\mathrm{C}$ in select groups in the Punjab region of Pakistan. J Clin Gastroenterol. 2001;33:407-411.

73. Paintsil E, Binka M, Patel A, Lindenbach BD, Heimer R. Hepatitis $C$ virus maintains infectivity for weeks after drying on inanimate surfaces at room temperature: implications for risks of transmission. J Infect Dis. 2014;209:1205-1211.

74. Aziz H, Raza A, Murtaza S, Waheed Y, Khalid A, Irfan J, Samra Z, Athar MA. Molecular epidemiology of hepatitis $C$ virus genotypes in different geographical regions of Punjab Province in Pakistan and a phylogenetic analysis. Int J Infect Dis. 2013;17:e247-253.

75. Pawlotsky JM. Hepatitis $C$ treatment: The data flood goes on-An update from the liver meeting 2014. Gastroenterology. 2015;148:468-479.

76. Hatzakis A, Chulanov V, Gadano AC, Bergin C, Ben-Ari Z, Mossong J, Schreter I, Baatarkhuu O, Acharya S, Aho I, Anand AC, Andersson $\mathrm{Ml}$, Arendt V, Arkkila P, Barclay K, Bessone F, Blach S, Blokhina N, Brunton CR, Choudhuri G, Cisneros L, Croes EA, Dahgwahdorj YA, Dalgard O, Daruich JR, Dashdorj NR, Davaadorj D, de Knegt RJ, de Vree M, Estes C, Flisiak R, Gane E, Gower E, Halota W, Henderson C, Hoffmann P, Hornell J, Houlihan D, Hrusovsky S, Jarcuska P, Kershenobich D, Kostrzewska K, Kristian P, Leshno M, Lurie Y, Mahomed A, Mamonova N, Mendez-Sanchez N, Norris S, Nurmukhametova E, Nymadawa P, Oltman M, Oyunbileg J, Oyunsuren Ts, Papatheodoridis G, Pimenov N, Prabdial-Sing N, Prins M, Radke S, Rakhmanova A, Razavi-Shearer K, Reesink HW, Ridruejo E, Safadi R, Sagalova O, Sanchez Avila JF, Sanduijav R, Saraswat V, Seguin-Devaux C, Shah SR, Shestakova I, Shevaldin A, Shibolet O, Silva MO, Sokolov S, Sonderup M, Souliotis K, Spearman CW, Staub T, Stedman C, Strebkova EA, Struck D, Sypsa $\mathrm{V}$, Tomasiewicz K, Undram L, van der Meer AJ, van Santen D, Veldhuijzen I, Villamil FG, Willemse S, Zuckerman E, Zuure FR, Puri P, Razavi $H$.The present and future disease burden of hepatitis $\mathrm{C}$ virus (HCV) infections with today's treatment paradigm-volume 2. J Viral Hepat. 2015;22 Suppl 1:26-45. 
77. Zaheer HA, Saeed U, Waheed Y, Karimi S, Waheed U. Prevalence and trends of hepatitis $\mathrm{B}$, hepatitis $\mathrm{C}$ and human immunodeficiency viruses among blood donors in Islamabad, Pakistan 2005-2013. J Blood Disorders Transf. 2014;5:1000217.

78. Naveed S, Qamar F, Zainab S, Sarwar G. A Survey Study on awareness of Hepatitis $C$ in different groups. World J Pharml Sci. 2014;2:2321-2331.

79. Aziz H, Raza A, Murtaza S, Waheed Y, Khalid A, Irfan J, Samra Z, Athar MA. Molecular epidemiology of hepatitis C virus genotypes in different geographical regions of Punjab Province in Pakistan and a phylogenetic analysis. Int $\mathrm{J}$ Infect Dis. 2013; 17:e247-253.

80. Bhawani Y, Raghava Rao P, Sudhakar V. Seroprevalence of transfusion transmissible infections among blood donors in a tertiary care hospital of Andhra Pradesh. Biol Med. 2010;2:45-48.

81. Gyawali S, Rathore DS, Shankar PR, Maskey M, Vikash KK. Injection practices in Nepal: health policymakers' perceptions. BMC Int Health Hum Rights. 2014;14:21.

82. Simonsen L, Kane A, Lloyd J, Zaffran M, Kane M. Unsafe injections in the developing world and transmission of bloodborne pathogens: a review. Bull World Health Organ. 1999;77:789-800.

83. John S, Miller R. Radical common sense: community provision of injectable contraception in Africa. Critical Issues in Reproductive Health. 2014;33:265-284

84. Thomson EC, Nastouli E, Main J, Karayiannis P, Eliahoo J, Muir D, McClure MO. Delayed anti-HCV antibody response in HIV-positive men acutely infected with HCV. AIDS. 2009;23:89-93.

85. Abdel-Aziz F, Habib M, Mohamed MK, Abdel-Hamid M, Gamil F, Madkour S, Mikhail NN, Thomas D, Fix AD, Strickland GT, Anwar W, Sallam I. Hepatitis C virus (HCV) infection in a community in the Nile Delta: population description and HCV prevalence. Hepatology. 2000;32:111-115.

86. Zia A, Ullah I, Ali S, Zia M, Mathew S, Fatima K, Raza A, Qadri I. Prevalent risk factors of HCV transmission in health care workers (HCWS) in Pakistan. Int J Pharm Pharm Sci. 2015;11:365-370.

87. Imran $\mathrm{M}$, Rafique $\mathrm{H}$, Khan $\mathrm{A}$, Malik $\mathrm{T}$. A model of bi-mode transmission dynamics of hepatitis $\mathrm{C}$ with optimal control. Theory Biosci. 2014;133:91-109

88. Safi SZ, Waheed Y, Sadat J, Solat-UI-Islam, Salahuddin S, Saeed U, Ashraf M. Molecular study of HCV detection, genotypes and their routes of transmission in North West Frontier Province, Pakistan. Asian Pac J Trop Biomed. 2012;2:532-536.

89. Kuo I, Ul-Hasan S, Galai N, Thomas DL, Zafar T, Ahmed MA, Strathdee SA. High HCV seroprevalence and HIV drug use risk behaviors among injection drug users in Pakistan. Harm Reduct J. 2006;3:26.

90. Khan A, Tareen AM, Ikram A, Rahman H, Wadood A, Qasim M, Khan K. Prevalence of HCV among the young male blood donors of Quetta region of Balochistan, Pakistan. Virol J. 2013;10:83.

91. Khan NU, Ali I, Ahmad NU, Iqbal A, Rehman LU, Munir I, Rehman MU, Khan S, Ali S, Siddique L, Swati ZA. Prevalence of active HCV infection among the blood donors of Khyber Pakhtunkwa and FATA region of Pakistan and evaluation of the screening tests for anti-HCV. Virol J. 2011:8:154.

92. Khanani MR, Somani M, Khan S, Naseeb S, Ali SH. Prevalence of single, double, and triple infections of HIV, HCV and HBV among the MSM community in Pakistan. J Infect. 2010;61:507-509.

93. Hafeez-ud-din, Siddiqui TS, Lahrasab W, Sharif MA. Prevalence of hepatitis $B$ and $C$ in healthy adult males of paramilitary personnel in Punjab. J Ayub Med Coll Abbottabad. 2012;24:138-140.

94. Akhtar M, KhanMA, ljaz T, Majeed S. Hepatitis C Virus Infection in Pregnant Women in Lahore, Pakistan: An Analytical Cross Sectional Study. International Journal of Agriculture Biology. 2014;16:160164.

95. Mathew S, Fatima K, Fatmi MQ, Archunan G, Ilyas M, Begum N, Azhar E, Damanhouri G, Qadri I. Computational docking study of p7 lon channel from HCV genotype 3 and genotype 4 and its interaction with natural compounds. PLoS One. 2015;10:e0126510.

96. Rafiq N, Younossi ZM. Younossi. Effects of weight loss on nonalcoholic fatty liver disease. Seminars in liver disease. Semin Liver Dis. 2008;28:427-433.

97. Perumpail RB, Wong RJ, Ha LD, Pham EA, Wang U, Luong $H$, Kumari R, Daugherty TJ, Higgins JP, Younossi ZM, Kim WR, Glenn JS, Ahmed A. Sofosbuvir and simeprevir combination therapy in the setting of liver transplantation and hemodialysis. Transpl Infect Dis. 2015;17:275-278.

98. Tunio SA, Bano S, Laghari ZA, Ali W, Shamim H, Afreen. U Seroprevalence of Hepatitis B and Hepatitis C among blood donors in Hyderabad, Pakistan. Gomal Journal of Medical Sciences. 2014;11:220-223.

99. Pfaender S, Heyden J, Friesland M, Ciesek S, Ejaz A, Steinmann J, Steinmann J, Malarski A, Stoiber H, Tsiavaliaris G, Bader W, Jahreis G, Pietschmann T, Steinmann E. Inactivation of hepatitis $C$ virus infectivity by human breast milk. J Infect Dis. 2013;208:1943-1952

100. Terrault NA, Dodge JL, Murphy EL, Tavis JE, Kiss A, Levin TR, Gish RG, Busch MP, Reingold AL, Alter MJ. Sexual transmission of hepatitis $\mathrm{C}$ virus among monogamous heterosexual couples: the HCV partners study. Hepatology. 2013;57:881-889.

101. Bibi S, Dars S, Ashfaq S, Ara Qazi R, Akhund S. Seroprevalence and risk factors for hepatitis $\mathrm{C}$ virus $(\mathrm{HCV})$ infection in pregnant women attending public sector tertiary care hospital in Hyderabad Sindh. Pak J Med Sci. 2013;29:505-508.

102. Ford N, Singh K, Cooke GS, Mills EJ, von Schoen-Angerer T, Kamarulzaman $A$, du Cros $P$. Expanding access to treatment for hepatitis $C$ in resource-limited settings: lessons from HIV/AIDS. Clin Infect Dis. 2012;54:1465-1472.

103. Chemaitelly H, Abu-Raddad LJ, Miller FD. An apparent lack of epidemiologic association between hepatitis $C$ virus knowledge and the prevalence of hepatitis $C$ infection in a national survey in Egypt. PLoS One. 2013;8:e69803.

104. Dhiman RK, Chawla YK. Minimal hepatic encephalopathy. Indian J Gastroenterol. 2009;28:5-16.

105. Ghany MG, Nelson DR, Strader DB, Thomas DL, Seeff LB; American Association for Study of Liver Diseases. An update on treatment of genotype 1 chronic hepatitis C virus infection: 2011 practice guideline by the American Association for the Study of Liver Diseases. Hepatology. 2011;54:1433-1444.

106. Sanchez-Tapias JM, Diago M, Escartin P, Enriquez J, RomeroGomez M, Barcena R, Crespo J, Andrade R, Martnez-Bauer E, Perez R, Testillano M, Planas R, Sola R, Garcia-Bengoechea M, Garcia-Samaniego J, Munoz-Sanchez M, Moreno-Otero R; TeraViC-4 Study Group. Peginterferon-alfa2a plus ribavirin for 48 versus 72 weeks in patients with detectable hepatitis $C$ virus RNA at week 4 of treatment. Gastroenterology. 2006;131:451-460.

107. Backus LI, Boothroyd DB, Phillips BR, Belperio P, Halloran J, Mole LA. A sustained virologic response reduces risk of all-cause mortality in patients with hepatitis C. Clin Gastroenterol Hepatol. 2011;9:509-516.e1.

108. Morgan RL, Baack B, Smith BD, Yartel A, Pitasi M, Falck-Ytter $Y$. Eradication of hepatitis $C$ virus infection and the development of hepatocellular carcinoma: a meta-analysis of observational studies. Ann Intern Med. 2013;158:329-337.

109. Lewis H, Cunningham M, Foster G. Second generation direct antivirals and the way to interferon-free regimens in chronic HCV. Best Pract Res Clin Gastroenterol. 2012;26:471-485.

110. Cheng G, Peng B, Corsa A, Yu M, Nash M, Lee YJ, Xu Y, Kirschberg T, Tian Y, Taylor J, Link JO, Delaney W. 1172 antiviral activity and resistance profile of the novel HCV NS5A inhibitor GS-5885. Journal of Hepatology. 2012;56:S464. 